\title{
The Impact of Entrepreneurial Orientation Success Factors to Muslim SMESuccess
}

\author{
NadratunNafisah Abdul Wahab ${ }^{1}$,Muhammad Abdul Malik Saedon², Etmawati Bulkia ${ }^{3}$, \\ Salimah Yahaya ${ }^{4}$, Mohamad Khadafi Rofie ${ }^{5}$
}

\author{
${ }^{1}$ Faculty of Management and Economics, Sultan Idris Education University (UPSI) \\ ${ }^{2}$ Faculty of Art, Computing and Creative Industry, Sultan Idris Education University, Perak (UPSI), \\ ${ }^{3}$ Agency for Industrial Human Research and Development,Ministry of Industry Republic of Indonesia \\ ${ }^{4}$ Academy for Islamic Studies and Contemporary (ACIS),UniversitiTeknologi Mara (UiTM), \\ Terengganu Branch, Campus Dungun, \\ ${ }^{5}$ School of Language, Civilization and Philosophy (SLCP), University Utara Malaysia (UUM)Sintok, Kedah, \\ ${ }^{1}$ nadratun@fpe.upsi.edu.my, ${ }^{2}$ abdulmalik@fskik.upsi.edu.my, ${ }^{3}$ etibulkia@gmail.com, \\ 4salimahyahya@uitm.edu.my, ${ }^{5}$ khadafi@uum.edu.my
}

Article History: Received: 10 November 2020; Revised: 12 January 2021; Accepted: 27 January 2021; Published online: 05 April 2021

\begin{abstract}
This studypresentsa research of the multidimensional entrepreneurial orientation (innovation, risk and proactive) in relation to the Muslim SME success. Thus far, past literatures shown that limited study of Muslim SME success. This study was conducted in the form of survey, with data being gathered from 122 firms (operating above 3 years) selected through simple random sampling from 2286 Muslim SME in Malaysia. The results show that innovation and proactivefactorshave relationshipsto SME Muslim success. The results shed new light on the theory and practice. This finding contributestoRBV theory and to the field of Islamic entrepreneurship focusing on Muslim SME success.
\end{abstract}

Keywords:Entrepreneurial orientation, Muslim SME success,innovative, proactive, RBV

\section{Introduction}

Malaysia that is known as a Muslim country, demands of Muslim Small Medium Enterprises (SMEs)success. It is because of SME is one of the big contributor to the economy. It has been reported by SMECorp. (2017), that 97 per cent of all businesses in the country are from the SME sector. These businesses also accounted for 36 per cent of the country's Gross Domestic Product (GDP) in 2016, 65 per cent of all jobs and 18 per cent of the country's exports (Bajet, 2017; SMECorp, 2017).From the entire SME industry only 37 percent are Muslim SMEs (Parlimen, 2016; SMECorp, 2016). This has led to the importance role of SMEs in the country. So far, this phenomenon course essentialquestions remain about the role of Muslim SMEs success in Malaysia as it is seen need to be further enhanced.The involvement of Muslim SMEs by 37 percent is still weak. This is because the percentage of the Malaysian Muslim population is 68.6 percent (Jabatan Statistik, 2013; SMECorp, 2016). Compared to these two percentages, it is clear that the gap is 11.6 percent. This should be noted in the context of increasing the number of successful Muslim SMEs. Therefore, to address this, research needs to be done to find the success factors that contribute to the Muslim SME success. (Zulkifli \& Rosli, 2013).

The industry to date has 5,726 halal firms registered in Malaysia. Of these firms, only 2,290 or 40 percent are Muslim firms (Halfest, 2016). Therefore, this evidence shows the failure of Muslim firms in the halal industry which should have preceded other non-Muslim firms. The issue of Muslim SME success has become an obligation to deal with immediately. More serious action is needed to better Muslim SME participation and more research needs to be done to enhance this very low percentage(SMECorp, 2016).Statistics released by the Companies Commission of Malaysia (SSM), reports released in 2012 to 2015 show that the number of SMEs involved in winding up and cancellation under section 308 is increasing significantly(Suruhanjaya Syarikat, 2012).Meanwhile, statistics for the SME license renewal category were reported to decline by 58\%(Suruhanjaya Syarikat, 2013). The situation is illustrated by the Companies Commission of Malaysia (SSM) that many of the SMEs leading to failures.

\section{Literature Review}

The SMEs failure is an indication of the effectiveness of Resource Based View (RBV) theory in previous studies. This failure and low-performing Muslim SMEs makeraisesquestions about the effectiveness of using the RBV theory in Muslim SME success. Therefore, the Muslim SMEs issue using the RBV theory should be taken into account to determine the factors that influence the success(Julienti, 2011; Zulkifli \& Rosli, 2013).

Simpson et al. (2013)explain success measures involving financial and non-financial. It is measured directly based on the definition of success and the success factors (Watson et al., 1998). SMEs are made up of two 
sections, namely entrepreneurs and SMEs. These two parts interact with each other. Most entrepreneurs find themselves as a business entity (the business)where they can determine the success of their SMEs(Balog, Baker, \& Walker, 2014).

Entrepreneurial Orientation (EO) is ideal for a fast-moving SME environment where entrepreneurs who practice it can build a better position in the market (Davis et al., 2010). It also develops strategies and addresses the market. Innovative, risk and proactive SMEs make them better position than their competitors (Aminul, Aktaruzzaman, Abu, \& Syed, 2011; Norshafizah, 2012). This statement was agreed upon by previous researchers such as Abebe (2014), al-Dhaafri and al-Swidi (2016), Amin, Thurasamy, Aldakhil and Kaswuri (2016), Anders, Samuelsson, Anders and Samuelsson (2016), Eggers et al. and 2013, Kantur, (2016), Vora dan Polley (2012), Wolff, Pett and Ring (2015) and Zhag et al. (2014).

It is clear that the EO elements of innovative, risk and proactive elements are considered important to entrepreneurship and should be studied in the context of the Muslim SME success in Malaysia. It is a resource that can assist in enhancing entrepreneurial activities while ensuring the long-term of SMEs success(Barney, 2001).EO can create new business opportunities and Muslim SMEs can race ahead of their competitors in a healthy way and position their SMEs strategically in the market.

\section{Innovation}

Covin and Slevin (1989) state that innovation factor is an important factor and can be used as a key predictor of SME success. There are four types of innovations namely product, process, organization and marketing. The entrepreneurial process cannot be successful without the existence of innovation factors especially in the process of forming an organization, product or service. While SME organizations need to constantly incorporate innovation behaviors and implement them in every entrepreneurial action. In turn, innovation can enhance SMEs' ability to cope with changing market environment (Andersson et al., 2015; Ekpe, 2012). Innovative SMEs are focused on ways to facilitate the growth of SMEs by offering new products with high profitability and ensuring successful SMEs to compete in the market (Andersson et al., 2015).

Entrepreneurial innovation is associated with imagination or open-mindedness about the extent to which SMEs can go out of the way. Innovation is considered important at all levels (Eriksson \& Li, 2012). The process of innovation is developed by SMEs and requires considerable resources and technical knowledge (Hunter, 2012). One of the ways of the innovation process is through the involvement of workers working together to find ideas and to introduce new ways to SMEs. The involvement of these workers is considered to be an accomplishment of the job and appreciated by the employer. If this whole process of innovation goes wrong, these workers will not be punished. SMEs need to be open minded to allow workers to think outside their field of work as this process can lead organizations toward the creation of new knowledge and ideas (Andersson, Danilovic, \& Huang, 2015; França, Broman, Robèrt, Basile, \& Trygg, 2017; Mas-Tur \& Ribeiro, 2014; Yu, Nguyen, \& Chen, 2016).

Febianto (2011) says entrepreneurial innovation has been important since the beginning especially during the early stages of developing the concept of SME. This statement was supported by Schumpeter (1947) who defined entrepreneurship as doing something new or doing things in a new way (innovation)(Schumpeter, 1947; Fallatah, 2012). Internal innovation focuses on creating value for innovation within SME activities. This process of innovation can bring SMEs to competitive advantage because of the innovative efficiency that is growing in the organization and is difficult to replicate (Galindo \& Méndez, 2014).Innovative entrepreneurship makes their SMEs unique (Davis, 2013). Innovation is carried out in the form of small but continuous steps in terms of product creation and process improvement (Eriksson \& Li, 2012). Therefore, SMEs that are actively involved in innovation activities have a higher chance of achieving and maintaining competitive advantage over the long term (Chai, 2014).

ThereforeSMEs need to find and identify opportunities in the market through innovation (Javed, 2012). This opportunitycan be strategically positioned SMEs as they have the advantage of being the first mover (pioneer) in the market and taking advantage of new market opportunities. At the same time, itcan help SMEs to develop long-term strategies by converting old methods to new ones (Norshafizah, 2012). In developing innovation, what needed are entrepreneurial thinking, entrepreneurial leadership, strategic resource management culture and the use of entrepreneurial creativity.

Among the steps in implementing SME product innovation is direct access to customers' information through the Internet. This is a faster and better way to meet customers' need(Nuradli, Zainal, Faizah, \& Hanifah, 2004). 
While Zafir and Fazilah, (2011), state that innovations in SMEs through technology (such as information technology) help in obtaining low cost information and can provide higher returns (Candra \& Ashari, Reza, 2014; Syed et al., 2011). This is because through the information acquired, it can develop the market based on the evaluation of new customers. These assessments lead to new ways of solving customers' problem and thus creating new opportunities for SMEs (Davis, 2013).

In addition, developing and planning SME innovations need for guidance and support along with financial access (Dzulkarnain, 2014; Malaysia, 2015; Saad, 2014; SME Corporation, 2016). The innovation activities should be taken into consideration for example R\&D development, modernization of manufacturing, implementation of energy efficiency solutions, internationalization and digitization to facilitate and support the SMEs (Muller, Gagliardi, Caliandro, Bohn, \&Klitou, 2014).

While communication experts emphasize the tendency to master entrepreneurship and innovation (Abdulqadir, 2016; Arafat Muhammad, 2014; Georgellis, Joyce, \& Woods, 2000; Konrad, 2013; Marane, 2012; Nathan \& Lee, 2013; Pitkanen, Parvinen, \& Toytari, 2014; Drakopoulou \& Gotsis, 2007; Turró, Urbano, \& Peris-Ortiz, 2014; Ukko, 2013; Yu et al., 2016). Indevelopingcommunication innovation, a company can convey the spirit of entrepreneurship. The entrepreneurial spirit that is channeled through communication is seen as increasingly important as a source of innovation in almost every industry (Scuotto \& Morellato, 2013). Therefore, SMEs need to invest more in developing effective systems to further enhance the value of communication. For example in communication with customers, SMEs needs to be aware of the innovative features of the product being released and how it can benefit them.

Innovative SMEs have the ability to meet the needs of the community by generating creative ideas and thus creating opportunities in an effort to increase SME productivity and success (Maisarah \& Suhaila, 2013). Generally, entrepreneurs who practice innovation, have the skills and knowledge that are constantly being developed in accordance with their own SME policies. The innovation policy is aimed at developing a core competency then to grow their SMEs and further enhance their SME success. Therefore, innovation is an important factor and can be used as a predictor of the Muslim SME success(Zulkifli \& Rosli, 2013).

\section{Risk Taking}

SMEs must be strong enough in their decision-making to overcome obstacles and the ability to overcome all the dangers or risks of becoming successful SMEs (Campagnolo \& Vivel, 2012).Risk is defined by Frank H. Knight, (1885/1972) as uncertainty. The results of action in making decisions can only be measured after they are made. Relationship risk is associated with legal and political relations. Researcher Giglierano (1986) states that there are two types of risk. Firstly is "sinking boat" risk namely the concept of bad thinking (problems with time, feeling satisfied with the market, adequate marketing, unnecessary distribution approach and inappropriate pricing). The second is "no boat" risk (being very careful when it comes to opportunities, not taking courses of action, or slowing down opportunities) (Javed, 2012).

There are many examples of risky entrepreneurial activities that need to be taken to enhance SME success (Lebbe, 2015; Belás, Bilan, Demjan, \& Sipko, 2015; Busenitz, 1999; Hassan \& Abdullah, 2016; Huybrechts, Voordeckers, \& Lybaert, 2013; Kaliappen, 2014; Kraiczy, Hack, \& Kellermanns, 2015; Palich \& Bagby, 1995; Suhaimi, 2015; Thomas et al., 1985; Zahra, 2005). The study of entrepreneurial tendencies to take risks that make entrepreneurs successful is to take a conservative approach when making SME decisions such as measures to offer discounts or market expansion. Risk is usually associated with an investment that is expected to offer a high return on income (Miller dan Bromiley, 1990).

According to Younhee (2007) risks are categorized into three types which are financial risk, service-based risk and relationship risk. Risks associated with financial and service uncertainty, for example in relation to SME organizations where SMEs lose contracts or fail to obtain contracts, may result in the closure of SMEs in the event of a loss. Service-based risks, however, relate to new and unprecedented services. An example of an implementation that can also be risky is when it produces results that do not meet the desired results (Kreiser et al., 2013; Kuratko, Hornsby, \& Covin, 2014; Miller \& Bromiley, 1990) illustrate that entrepreneurs need to be willing to accept and forgive an error occurred.

An SME that wants to be more successful in their industry needs to take and manage risks (Hunter, 2012; Sebora \& Theerapatvong, 2010; Syed et al., 2011). The measurement of risk taking used in this study relates to SMEs who are bold and aggressive in enhancing profitability, but still of environmental importance. The success of SMEs to take risks is linked to firms' tendency to choose risky projects. However, SMEs adhere to 
environmental laws. While SMEs that encourage employees to maximize profits have the characteristics of firms that dare to take risks and aggressively seize opportunities (Covin \& Slevin, 1989). Therefore, the risk factor is seen as a relevant source to the study and is a factor that can be used as a predictor of the Muslim SME success.

\section{Proactive}

Lieberman and Montgomery (1988) highlight the proactive importance of entrepreneurship where entrepreneurs are the first mover in the industry. This enables them to have the advantage and strategy over competitors and in turn take advantage of the market. It is also suggested that as a first mover, entrepreneurs succeed in gaining a higher profit and thus have the advantage of being pioneers in building brand recognition in the market (Lumpkin \& Dess, 1996a).

Proactive tends to be associated with aggressive attitudes toward competitiveness (Kuratko et al., 2014; Miller, 2011). The relationship between proactive and successful SMEs can be enhanced if a quick action strategy is successfully developed. The proposed strategy should be appropriate in introducing new products or services. Proactive is the willingness to take action to compete with competitors through response. More proactive SMEs strive to be the first to introduce new products, services and administrative technologies and not simply respond to competition. Competition promoting proactive activities also helps SMEs to overcome inefficient organizational problems by introducing innovative ways and thinking of competitors' responses (Javed, 2012).

The proactive SMEs are always exposed to the activity of predicting market potential and predicting the actions that need to be taken to become a market leader (Lumpkin \& Dess, 1996a). Generally, the proactive SMEs refer to the stand in preparation and the aspirations of participating in fierce competition (Chai, 2014). Proactively refers to how an SME takes market opportunity in the process of producing a new product or service. The proactive activities of SMEs are created by seizing the opportunities that exist by building initiatives and "shaping the environment" influencing the next trend of competing demands.

Proactive entrepreneurial behavior within SMEs can contribute to SME success. This proactive entrepreneurial attitude is also said to overcome the problem of SME success even in the midst of an economic crisis (Zulkifli \& Rosli, 2013). Therefore, by taking proactive initiative, SMEs can anticipate and pursue new opportunities. The proactive entrepreneurs described it as a fast-paced SME in introducing new products or services. This is suggested by Miller who argues that an SME that runs a proactive entrepreneurship has the ability to lead the market and be competitive (Miller dan Bromiley, 1990).Looking at these proactive features, this factor can serve as a predictor of Muslim SME success.

Therefore, according to past study and Muslim SMEs in Malaysia, the entrepreneurial orientation factors which is innovative, risk and proactive need to be view and study separately. As the issue of success of Muslim SME success remains to be explored, researchers have chosen innovation, risk and proactive as independent variablefactors and Muslim SME success as the dependent variable to study relationships that exist.

\section{Problem Statement}

Previous entrepreneurial studies have found that innovation variables provide mixed and inconsistent results. Examples of such studiesGilbar (2015), Soininen, Puumalainen, Sjo, Syrja, Durst (2013) and Abidin (2014)disagree that innovation is a determining factor in SME success. This is because Muslim entrepreneurs are said to be less open to this factor. However, this view contradicts Drucker's (1985) notion that high rates of failure are due to entrepreneurs who are not grounded in innovation and do not apply innovation in their SMEs.(Wales, Parida, \& Patel, 2013). There are also researchers who support the innovation factor as a factor in SME success(Andersson et al., 2015; Lumpkin \& Dess, 1996b, 1996a; Maisarah \& Suhaila, 2013; Norshafizah, 2012).

There are mixed opinion on the role of risk factors in SME success. It has been said by previous researchers that when too much attention is given to risk variables, it can negatively impact the SME environment and success(Hussain, Ismail, \& Akhtar, 2015; Suhaila, Suhaily, \& Firdaus, 2013). Similarly, if entrepreneurs do not take the time to think about the work that needs to be done in building an SME, then entrepreneurs are always comfortable with the current situation and not trying to take risks. (Campagnolo \& Vivel, 2012; Lumpkin \& Dess, 1996a). However, earlier studies such asAndersson et al. (2015) dan Norshafizah (2012)finds that entrepreneurs who take the risk can make a more profitable offer to their customers. 
Previous studies have found that Muslim countries are losing their proactive Muslim entrepreneurship practices, which were once the backbone of Muslim entrepreneurs' success(Faizal et al., 2013). The findings of this study are also supported by Grine et al. (2015a)found that proactive factors among Muslim women entrepreneurs are weak. However, there have been studies that have shown that proactiveness is crucial to improving SMEs' performance during Malaysia's economic crisis(Zulkifli \& Rosli, 2013). Obviously, being proactive is one of the criteria of a Muslim entrepreneur but is less practiced among the entrepreneurs involved. Therefore, researchers have found that these variables need to be reviewed in the context of Muslim SMEs in Malaysia.

\section{Methodology}

This quantitative study was conducted on 122 selected firms through simple random sampling from 2286 PerbadananUsahawan Nasional Berhad (PUNB) entrepreneurs' (more than three years operation) in Malaysia. The relationship between the entrepreneurial orientation and the Muslim SME success according to the research objective is separate down into three hypotheses:

H1: Innovation has a significant relationship to Muslim SME success.

H2: Risk has a significant relationship to Muslim SME success.

H3: Proactively has a significant relationship to Muslim SME success.

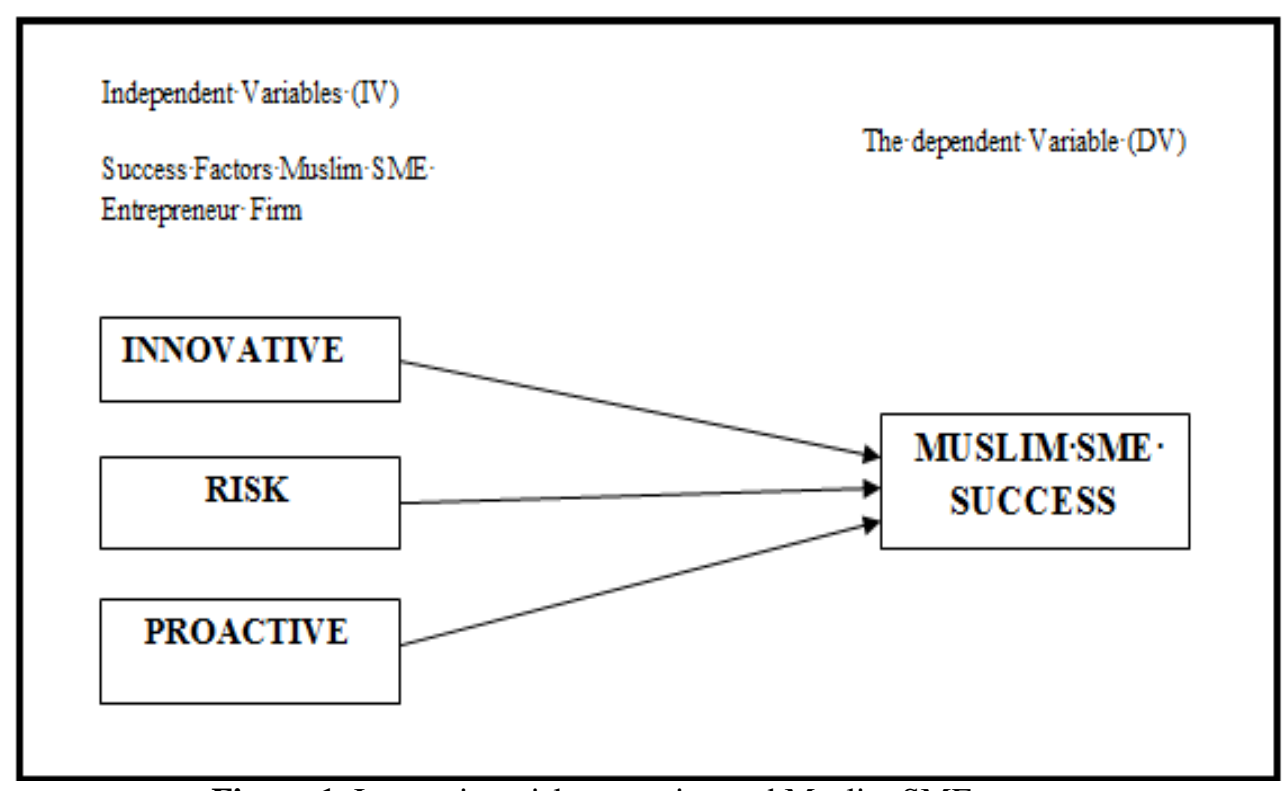

Figure 1. Innovative, risk, proactive and Muslim SME success

Table 1.Muslim SME success measurement

\begin{tabular}{ll}
\hline Item & (Section A) \\
\hline $\mathbf{1}$ & PKS sayamendapatkeuntunganmengikutjangkaan \\
$\mathbf{2}$ & Jualanproduk/servis PKS sayamenguntungkan \\
$\mathbf{3}$ & Perkembanganpusinganjualansayamemuaskan \\
$\mathbf{4}$ & PKS sayatelahmencapaititikpulang modal (balik modal) \\
$\mathbf{5}$ & PKS sayaberjayamemenuhipermintaanpasaran \\
$\mathbf{6}$ & Secarakeseluruhannya, PKS sayaadalahmemuaskan \\
$\mathbf{7}$ & PKS sayaberkembangseiringdengankerjayasaya \\
$\mathbf{8}$ & Pelangganberpuashatidenganproduk/servis PKS saya \\
$\mathbf{9}$ & PKS sayamempunyaipelanggan-pelanggan yang setia \\
$\mathbf{1 0}$ & Pekerjaberpuashatidengan PKS saya \\
$\mathbf{1 1}$ & Hubungan PKS denganpembekaladalahbaik \\
$\mathbf{1 2}$ & Imej PKS sayaditerima oleh komuniti \\
$\mathbf{1 3}$ & Hubungansesama PKS di kawasansayaadalahbaik
\end{tabular}


14 PKS sayamembuatkankehidupan dan pekerjaansayaseimbang

15 PKS sayatidakmenghadapimasalahpulangankeatasjualan

16 Pusingan modal PKS sayaadalahmencukupi

17 Untungbersih PKS sayaadalahmencukupi

18 Segmenpasaransediaadaadalahmencukupiuntuk PKS saya

19 Kadar pulangan modal PKS sayaadalahbaik

20 Jumlahjualan PKS sayabertambahbaik

21 Segmenpasaran PKS sayabertambahbaik

22 Alirankewangan PKS sayaadalahtetap

Source: (Hazlina et al., 2011)

Innovation measurement was adapted from the study (George \& Marino, 2011). This construct was developed by Miller (1983) and (Covin \& Slevin, 1989). The list of measurement items is as in Table 2.

Table 2.Innovation measurement

\section{Items (Section B)}

$1 \quad P K S$ sayamemberipenekanan yang kuatkepadapembangunanproduk/perkhidmatan $(R \& D)$

2 PKS sayaberoperasimenggunakanteknologiterkini

3 Kepimpinan PKS sayasentiasamenerima idea-idea baru

4 PKS sayatelahmemasarkanbanyakproduk/perkhidmatanbarudalamtempoh 3 tahun yang lalu

$5 \quad$ PKS sayakerapmengeluarkanproduk/perkhidmatanbaru

Source: (D. Miller \& Friesen, 1982)

In this research, risk taking measures were adapted from the study George dan Marino (2011)and assessed using a Likert 5 scale. This construct was developed by Miller (1983) and Covin and Slevin (1989) also Miller (2011). The list of measurement items is as shown in Table 3.

Table 3.Risk measurement

\begin{tabular}{ll}
\hline No & Items (Section C) \\
\hline $\mathbf{1}$ & PKS sayacenderunguntukmemilihprojek-projek yang berisiko \\
$\mathbf{2}$ & PKS sayamengikutakta-aktaberkaitanisualamsekitar \\
$\mathbf{3}$ & PKS sayamenggalakkanpekerjabersikaplebihberaniuntukmemaksimumkankeuntungan \\
$\mathbf{4}$ & PKS sayamenggalakkanbersikapagresifuntukmerebutpeluang \\
\hline
\end{tabular}

Source: (Miller \& Friesen, 1982)

The definition of proactive operations in this study is the tendency to succeed in competition. Therefore, proactive measurements were adapted from the George dan Marino (2011)and assessed using 5 item Likerts scale. This construct was developed by Miller (1983) and Covin dan Slevin (1989)and Miller (2011). The list of measurement items is as shown in Table 4.

Table 4. Proactive measurement

\begin{tabular}{ll}
\hline Items (Section D) \\
\hline 1 & PKS sayamendahuluipesaingdalammemperkenalkanteknikoperasibaru \\
2 & PKS sayamengamalkanpersainganuntukmengatasikedudukanpesaing di pasaran \\
3 & PKS sayamempunyaiinisiatiftindakanmelebihipesaing \\
4 & PKS sayamendahuluipesaingdalammemperkenalkanproduk/ perkhidmatanbaru \\
5 & PKS sayamendahuluipesaingdalammemperkenalkanteknikpentadbiranbaru \\
\hline Source(Miller \& Friesen, 1982)
\end{tabular}

Source:(Miller \& Friesen, 1982) 


\section{Consistency Reliability}

For consistency reliability (CR)assessment, the internal consistency reliability should be greater than 0.7(Hair et al., 2014). The results of this study showed that the composite reliability values 0.917 (Muslim SME success), 0.871 (innovation), 0.845 (risk) and 0.914 (proactive). This result shows that all variables have high value for internal consistency reliability. Table 5 shows the reliability values of the composite variables. All the average values of the extracted variants for the constructs exceeded 0.50 , which ranged from $0.5-0.7$.

Table 5.Model measurement

\begin{tabular}{|c|c|c|c|c|c|}
\hline $\begin{array}{l}\text { Latent } \\
\text { Variables }\end{array}$ & Predictors & Loading & $\begin{array}{l}\text { Composite } \\
\text { Reliable }\end{array}$ & AVE & $\begin{array}{l}\text { Discriminant } \\
\text { Validity }\end{array}$ \\
\hline & Muslim SME success 2 & 0.618 & 0.917 & 0.502 & Yes \\
\hline & Muslim SME success5 & 0.734 & & & \\
\hline & Muslim SME success6 & 0.784 & & & \\
\hline & Muslim SME success7 & 0.692 & & & \\
\hline & Muslim SME success8 & 0.767 & & & \\
\hline & Muslim SME success10 & 0.692 & & & \\
\hline & Muslim SME success 11 & 0.757 & & & \\
\hline & Muslim SME success12 & 0.775 & & & \\
\hline & Muslim SME success 13 & 0.709 & & & \\
\hline & Muslim SME success 14 & 0.64 & & & \\
\hline & Muslim SME success 19 & 0.599 & & & \\
\hline \multirow[t]{5}{*}{ Innovation } & Innovation 1 & 0.694 & 0.871 & 0.576 & Yes \\
\hline & Innovation 2 & 0.716 & & & \\
\hline & Innovation 3 & 0.77 & & & \\
\hline & Innovation 4 & 0.816 & & & \\
\hline & Innovation 5 & 0.793 & & & \\
\hline \multirow[t]{3}{*}{ Risk } & Risk 2 & 0.8 & 0.845 & 0.646 & Yes \\
\hline & Risk 3 & 0.8 & & & \\
\hline & Risko 4 & 0.81 & & & \\
\hline \multirow[t]{5}{*}{ Proactive } & Proactive 1 & 0.789 & 0.914 & 0.68 & Yes \\
\hline & Proactive 2 & 0.831 & & & \\
\hline & Proactive 3 & 0.827 & & & \\
\hline & Proactive4 & 0.865 & & & \\
\hline & Proactive 5 & 0.809 & & & \\
\hline
\end{tabular}

Table 6 shows the VIF values of the three sets of innovations, risk and proactive, the values of all setsare reported less than 5 predictors and no collinearity issues for each predictor variable.

Table 6.Collinearity

\begin{tabular}{lll}
\hline Variables & VIF & VIF $>\mathbf{5}$ \\
\hline Innovation & 2.213 & No \\
Risk & 2.244 & No \\
Proactive & 2.568 & No \\
\hline
\end{tabular}

The path coefficient values in Table 7 showthat the critical values used to identify the significance of the twotailed t-values. From the table, it can be seen that the t-value of innovation is 3.199 and p value of 0.001 and proactive value of 1.960 and $\mathrm{p}$ of 0.051 . While for therisk variableis not significant. 
Table 7.Path Coefficientmodel and $\mathrm{p}$ value

\begin{tabular}{|c|c|c|c|c|c|}
\hline Hypothesis & Relationship & $\begin{array}{l}\text { Path } \\
\text { Coefission }\end{array}$ & t-value & p-value & Result \\
\hline $\mathrm{H} 1$ & $\begin{array}{l}\text { Innovation } \rightarrow \text { Muslim } \quad \text { SME } \\
\text { success. }\end{array}$ & 0.313 & 3.199 & 0.001 & Significant \\
\hline $\mathrm{H} 2$ & Risk $\rightarrow$ Muslim SME success. & 0.031 & 0.308 & 0.758 & $\begin{array}{l}\text { Not } \\
\text { significant }\end{array}$ \\
\hline H3 & $\rightarrow \quad$ Muslim & 0.189 & 1.960 & 0.051 & Significant \\
\hline
\end{tabular}

Table 8.Hypotheses Result

\begin{tabular}{lll}
\hline Hypothesis & Variables & Result \\
\hline H1 & $\begin{array}{l}\text { Innovation has the positive significant relationship to Muslim SME } \\
\text { success }\end{array}$ & Significant \\
H2 & Risk taking has no significant relationship to Muslim SME success & $\begin{array}{l}\text { Not } \\
\text { significant }\end{array}$ \\
H3 & Proactive has positive significant relationship to SME Muslim success & Significant \\
\hline
\end{tabular}

\section{The Role of Innovation in the Success of Muslim SMEs}

The findings of this study show that the relationship of innovation and the Muslim SME success is supported. As such, entrepreneurship agencies need to think of strategies to foster greater innovation in Muslim SMEs. The focus on innovation should be given to research $(R \& D)$ and technology leadership. Encouragement should also be given to SMEs to regularly produce new products and services that can compete in the market. In addition, SMEs need to be sensitive to changes so that their products and services are up to date.

Through innovation, Muslim SMEs need to focus on the process of designing new methods of production and service in line with Miller's (1983) recommendation. In addition, Muslim SMEs are also being urged to persistently carry out activities based on research and development (R\&D), technology and innovation. At the same time, SMEs need to practice efficiency in the speed of identifying needs, as well as quickly providing regularly updated product or service lines as recommended by theCovin, Slevin (1989;) dan Miller ( 2011).

Thus, the role of the government and the entrepreneurial agencies is vital in accelerating the implementation of innovation by Muslim SMEs through industry-friendly policies. These include matching sessions between research institutions and industry, information exchange, investment incentives, monitoring and enforcement of policies. In this regard, more aggressive efforts need to be made by governments and entrepreneurship agencies in promoting innovation as an ongoing practice in SMEs.

\section{The Role of Risk to the Success of Muslim SMEs}

The role of risk constructs is not significant with Muslim SME success. Therefore, to promote the success of Muslim SMEs, workshops and talks on awareness of risk taking need to be held throughout Malaysia. The success of Muslim SMEs should be supported by the actions of SMEs who are bold in choosing projects that are risky, take care of environmental issues, have employees who are brave enough to maximize profits and practice aggressive firms' activities to seize opportunities. 


\section{The Proactive Role of the Success of Muslim SMEs}

The proactive role has a significant relationship to Muslim SMEs success. Thus, the proactive factor in leading amongSMEs competitors has been proven in this study to increase the Muslim SME success. For proactive success factor, Muslim SMEs have an aggressive tendency to introduce and apply new ideas, procedures / technologies as well as aggressively act to sell and market their new products as suggested byCovin dan Slevin (1989). In addition, proactive practiceis also carried out by the management of Muslim SMEs to constantly look for opportunities outside of existing business areas. Muslim SMEs also focus on predicting future changes and needs in line with the findings obtained byMiller (2011).

\section{Conclusion}

Overall, the objective of researching multidimensional entrepreneurial orientation factors (innovation, risk and proactive) to SME Muslim success has been met. The results show that innovation and proactive have a relationship to SME Muslim success. The results of this study contribute new finding on Muslim entrepreneurship toResource Based View (RBV) theory. On the practical side, entrepreneurship agencies can look at the internal influences (innovative and proactive) more broadly in developing strategies and policies to promote the success of Muslim SMEs. Finally, further studies are needed and a great focus on Muslim SME success could produce interesting findings that account more understanding on the factors that influence Muslim SMEs to achieve success.

\section{References}

1. Abdulqadir, R. A. A.-J. (2016). Entrepreneurial orientation, absorptive capacity, market orientation and technological innovation capabilities of smes in Kurdistan, Iraq. Universiti Utara Malaysia.

2. Ahmed Lebbe, A. R. (2015). Relationship between risk and return in sukuk market. Universiti Utara Malaysia.

3. Aminul, M. I., Aktaruzzaman, M. K., Abu, Z. M. O., \& Syed, M. A. (2011). Effect of entrepreneur and firm characteristics on the business success of Small and Medium Enterprises (SMEs) in Bangladesh. International Journal of Business and Management, 6(3), 289-299.

4. Andersen, J., \& Samuelsson, J. (2016). Resource organization and firm performance: How entrepreneurial orientation. International Journal of Entrepreneurial Behavior \& Research, 22(3), 346374.

5. Andersson, S., Danilovic, M., \& Huang, H. (2015). Success factors in Western and Chinese born global companies. Scientific Research Publishing, (March), 25-38.

6. Arafat Muhammad, N. (2014). The relationship between intellectual capital, innovation capability with firm age and firm performance. Universiti Utara Malaysia.

7. Bajet, U. (2017). Menjamin perpaduan dan pertumbuhan ekonomi, menghemah perbelanjaan inklusif, mensejahtera kehidupan rakyat seluruh. Ucapan Bajet Tahun 2017.

8. Balog, A. M., Baker, L. T., \& Walker, A. G. (2014). Religiosity and spirituality in entrepreneurship: A review and research agenda. Journal of Management, Spirituality \& Religion, 11(2), 159-186.

9. Barney, J. B. (2001). Resource-based theories of competitive advantage : A ten- year retrospective on the resource-based view. Journal of Management, 27, 643-650.

10. Belás, J., Bilan, Y., Demjan, V., \& Sipko, J. (2015). Entrepreneurship in sme segment: Case study from the Czech Republic and Slovakia. Amfiteatru Economic, 17(38), 308-326.

11. Benjamin, A. C., Martin, G., Franco, A., \& Agarwal, R. (2013). Absorptive capacity, firm performance, and the moderating role of entrepreneurial orientation. Strategic Management Journal, 87(June 2011), 12.

12. Busenitz, L. W. (1999). Entrepreneurial risk and strategic decision making: It's a matter of perspective. The Journal of Applied Behavioral Science, 35(3), 325-340.

13. Campagnolo, G., \& Vivel, C. (2012). Before Schumpeter: Forerunners of the theory of the Entrepreneur in 1900 s German political economy - Werner Sombart, Friedrich von Wieser. In The European Journal of the History of Economic Thought (Vol. 19, pp. 908-943).

14. Chai, Y. K. (2014). The relationship between strategic entrepreneurship and performance of Small And Medium Enterprises in Malaysia. Universiti Utara Malaysia.

15. Covin, J. G., \& Slevin, D. P. (1989). Strategic management of small firms in hostile and benign environments. Strategic Management Journal, 10(1), 75-87.

16. Davis, M. K. (2013). Entrepreneurship: An Islamic perspective. Int. J. Entrepreneurship and Small Business, 20(1), 63-69.

17. Dzulkarnain, M. (2014). Kesan penyederhana orientasi pasaran dan penyertaan ahli-ahli terhadap hubungan antara orentasi keusahawanan dan prestasi perniagaan firma koperasi. Universiti Utara 
Malaysia.

18. Eggers, F., Kraus, S., Hughes, M., Laraway, S., \& Snycerski, S. (2013). Implications of customer and entrepreneurial orientations for SME growth. Management Decision, 51(3), 524-546.

19. Faizal, P. R. M., Ridhwan, a. a. M., \& Kalsom, a. W. (2013). The entrepreneurs characteristic from alQuran and al-Hadis. International Journal of Trade, Economics and Finance, 4(4), 191-196.

20. Fallatah, H. (2012). Women Entrepreneurs in Saudi Arabia: Investigating strategies used by successful Saudi women entrepreneurs. Researcharchive.Lincoln.Ac.Nz. Lincoln University.

21. França, C. L., Broman, G., Robèrt, K.-H., Basile, G., \& Trygg, L. (2017). An approach to business model innovation and design for strategic sustainable development. Journal of Cleaner Production, 140, 155166.

22. Galindo, M.-Á., \& Méndez, M. T. (2014). Entrepreneurship, economic growth, and innovation: Are feedback effects at work? Journal of Business Research, 67(5), 825-829.

23. George, B. A., \& Marino, L. (2011). The epistemology of entrepreneurial orientation: Conceptual formation, modeling, and operationalization. Entrepreneurship: Theory and Practice, 35(5), 989-1024.

24. Georgellis, Y., Joyce, P., \& Woods, A. (2000). Entrepreneurial action, innovation and business performance: the small independent business. Journal of Small Business and Enterprise Development, 7(1), 7-17.

25. Gilbar, G. G. (2015). The Muslim big merchant-entrepreneurs of the Middle East, 1860-1914. Die Welt Des Islams, 43(1), 1-36.

26. Grine, F., Fares, D., \& Meguellati, A. (2015). Islamic spirituality and entrepreneurship: A case study of women entrepreneurs in Malaysia. The Journal of Happiness \& Well-Being, 3(1), 41-56.

27. Hair, J. F., Hult, J. G. T. M., Ringle, C. M., \& Sarstedt, M. (2014). Partial Least Squares Structural Equation Modeling ( Pls-Sem ). SAGE Publications.

28. Halfest. (2016). Halal fiesta (HALFEST) 2016. Teks Ucapan.

29. Hassan, S. A.-D., \& Abdullah, A.-S. (2016). The impact of total quality management and entrepreneurial orientation on organizational performance. International Journal of Quality \& Reliability Management, 33(5), 597-614.

30. Hunter, M. (2012). Some of the misconceptions about entrepreneurship. Economics Management and Financial Markets, 7(2), 55-104.

31. Hussain, J., Ismail, K., \& Akhtar, C. S. (2015). Linking entrepreneurial orientation with organizational performance of Small and Medium sized enterprises: A conceptual approach. Asian Social Science, 11(7), 1-10.

32. Huybrechts, J., Voordeckers, W., \& Lybaert, N. (2013). Entrepreneurial risk taking of private family firms. Family Business Review, 26(2), 161-179.

33. Irawan, F. (2011). Shariah compliant model of business entities. Social Sciences, 1, 130-149.

34. Jabatan Statistik, M. (2013). Jumlah penduduk mengikut kumpulan etnik, agama, jantina dan negeri, Malaysia, 2010. Jumlah Penduduk Malaysia (Vol. 53). Retrieved from www.statistic.gov.my

35. Javed, N. (2012). The mediating effect of corporate entrepreneurship on the relationship between structural , managerial, cultural, environmental factors and organizational performance in the State Government Higher Education Institutions of Pakistan. Universiti Utara Malaysia.

36. Kaliappen, N. (2014). Strategic match and effects of competitive strategy, market orientation and innovation strategy on hotels' performance: The catalyst for economic growth of a Nation. PhD Thesis. Universiti Utara Malaysia.

37. Kantur, D. (2016). Strategic entrepreneurship: Mediating the entrepreneurial orientation- performance link. Management Decision, 54(1), 24-43.

38. Konrad, E. D. (2013). Cultural entrepreneurship: The impact of social networking on success. Creativity and Innovation Management, 22(3), 307-319.

39. Kraiczy, N. D., Hack, A., \& Kellermanns, F. W. (2015). What makes a family firm innovative? CEO risk-taking propensity and the organizational context of family firms. Journal of Product Innovation Management, 32(3), 334-348.

40. Kreiser, P. M., Marino, L. D., Kuratko, D. F., \& Weaver, K. M. (2013). Disaggregating entrepreneurial orientation: The non-linear impact of innovativeness, proactiveness and risk-taking on SME performance. Small Business Economics, 40(2), 273-291.

41. Kuratko, D. F., Hornsby, J. S., \& Covin, J. G. (2014). Diagnosing a firm's internal environment for corporate entrepreneurship. Business Horizons, 57(1), 37-47.

42. Lily Julienti, A. B. (2011). Relationship between firm resources and product innovation perfomance in Malaysian Small Medium Enterprises: the moderating role of age and size. Universiti Utara Malaysia.

43. Lumpkin, G. T., \& Dess, G. G. (1996a). Clarifying the entrepreneurial orientation construct and linking it to performance. Academy of Management Review, 21(1), 135-172.

44. Lumpkin, G. T., \& Dess, G. G. (1996b). The entrepreneurial clarifying it construct and linking 
orientation. Academy of Management Review, 21(1), 135-172.

45. Maisarah, A., \& Suhaila, A. K. (2013). Characteristics of entrepreneurs and the practice of Islamic values in influencing the success of Small Medium Enterprises in Kelantan and Selangor. Journal of Social and Development Sciences, 4(5), 229-235.

46. Malaysia, B. N. (2015). Strategi pembangunan PKS.

47. Marane, B. M. O. (2012). The influence of organizational culture, innovation drivers, and information technology capability on innovation capability of manufacturing firms in Iraq. Thesis.

48. Mas-Tur, A., \& Ribeiro, S. D. (2014). The level of innovation among young innovative companies: The impacts of knowledge-intensive services use, firm characteristics and the entrepreneur attributes. Service Business, 8(1), 51-63.

49. Michael, A. (2014). Electronic commerce adoption, entrepreneurial orientation and Enterprise (SME) performance. Journal of Small Business and Enterprise Development, 111(8), 1238-1269.

50. Miller, D. (2011). Miller (1983) revisited: A reflection on EO research and some suggestions for the future. Entrepreneurship: Theory and Practice, 35(5), 873-894.

51. Miller, D., \& Friesen, P. H. (1982). Innovation in Conservative and Entrepreneurial Firms : Two Models of Strategic Momentum. Strategic Management Journal, 3(1), 1-25.

52. Miller, K. D., \& Bromiley, P. (1990). Strategic Risk and Corporate Performance: an Analysis of Alternative Risk Measures. Academy of Management Journal, 33(4), 756-779.

53. Mohd Saad, R. (2014). Hubungan antara perancangan perniagaan, sumber pembiayaan dan persekitaran luaran dengan prestasi perniagaan: Kajian empirikal PKS di Malaysia. Universiti Utara Malaysia.

54. Muslim, A., Ramayah, T., Abdullah, M. A., \& Aznur, H. K. (2016). The effect of market orientation as a mediating variable in the relationship between entrepreneurial orientation and SMEs performance. Nankai Business Review International Article, 10(3), 560-571.

55. Nathan, M., \& Lee, N. (2013). Cultural diversity, innovation, and entrepreneurship: Firm-level evidence from London. Economic Geography, 89(4), 367-394.

56. Noor Hazlina, A., Wilson, C., \& Kummerow, L. (2011). Assessing the dimensionality of business success: The perspectives of Malaysian SME owner-managers. Journal of Asia-Pacific Business, 12(3), 207-224.

57. Norshafizah, H. (2012). Business performance of women-owned SMEs in Malaysia: Learning and entrepreneurial orientations and the mediating roles of competitive advantage. Universiti Utara Malaysia.

58. Novika Candra, A., \& Ashari, Reza, N. (2014). Technology readiness and E-commerce adoption among entrepreneurs of SMEs in Bandung city, Indonesia. Gadjah Mada International Journal of Business, 16(1), 69-88.

59. Nuradli Ridzwan Shah, M. D., Mohd Zainal Munshid, H., Faizah, M. K., \& Hanifah, A. H. (2004). ECommerce in Islamic perspectives. Accounting and Finance.

60. Palich, L. E., \& Ray Bagby, D. (1995). Using cognitive theory to explain entrepreneurial risk-taking: Challenging conventional wisdom. Journal of Business Venturing, 10(6), 425-438.

61. Parlimen, L. (2016). Parlimen ketiga belas penggal ketiga mesyuarat kedua. Retrieved from http://www.parlimen.gov.my/

62. Pitkänen, I., Parvinen, P., \& Töytäri, P. (2014). The significance of the new venture's first sale: The impact of founders' capabilities and proactive sales orientation. Journal of Product Innovation Management, 31(4), 680-694.

63. Sarah Drakopoulou, D., \& Gotsis, G. (2007). The interrelationships between entrepreneurship and religion. The International Journal of Entrepreneurship and Innovation, 8(2), 93-104.

64. Scuotto, V., \& Morellato, M. (2013). Entrepreneurial knowledge and digital competence: Keys for a success of student entrepreneurship. Journal of the Knowledge Economy, 4(3), 293-303.

65. Sebora, T. C., \& Theerapatvong, T. (2010). Corporate entrepreneurship: A test of external and internal influences on managers' idea generation, risk taking, and proactiveness. International Entrepreneurship and Management Journal, 6(3), 331-350.

66. Simpson, M., Padmore, J., \& Newman, N. (2013). Towards a new model of success and performance in SMEs. International Journal of Entrepreneurial Behavior \& Research, 18(3), 264-285.

67. SME Corporation Berhad (SMECorp). (2017). SME Annual report 2016/17. Retrieved from http://www.smecorp.gov.my/vn2/node/1856

68. SME Corporation Berhad (SMRCorp). (2016). SME development policies and programmes.

69. Soininen, J. S., Puumalainen, K., Sjo, H., Syrja, P., \& Durst, S. (2013). Entrepreneurial orientation in small firms - values-attitudes-behavior approach. International Journal of Entrepreneurial Behavior \& Research, 19(6), 611-632.

70. Stefanovi, I., Rankovi, L., \& Proki, S. (2011). Entrepreneurs' motivational factors : Empirical evidence from Serbia. Serbian Journal of Management, 6(1), 73-83.

71. Suhaila, N., Suhaily, M. S., \& Firdaus, M. S. (2013). Faktor-faktor penyumbang kepada kejayaan dan 
kegagalan Perusahaan Kecil dan Sederhana (PKS) bumiputera di Malaysia. Fakulti Pengurusan Dan Muamalah, Kolej Universiti Islam Antarabangsa Selangor, 191-200.

72. Suhaimi, I. (2015). The relationship between risk management committee characteristics and modified audit opinion in Malaysia, (January).

73. Suriati, Z. A. (2014). Innovation process, innovation outcome and firm's performance in the malaysian electrical and electronic industry. Universiti Utara Malaysia.

74. Suruhanjaya Syarikat, M. (2012). Pernyataan visi SSM nilai-nilai korporat. Putrajaya.

75. Suruhanjaya Syarikat, M. (2013). SSM Annual Report 2013. Putrajaya.

76. Syed, S. A., Mohd Fauzi, M. J., \& Nor Asiah, O. (2011). An empirical study of success factors of women entrepreneurs in southern region in Malaysia. International Journal of Economics and Finance, 3(2), 166175.

77. Thomas, I., Howard, S. \&, \& Baird, I. S. (1985). A contingency model toward of strategic risk. The Academy of Management Review, 10(2), 230-243.

78. Torugsa, N. A., O'Donohue, W., \& Hecker, R. (2012). Capabilities, proactive CSR and financial performance in SMEs: Empirical evidence from an Australian manufacturing industry sector. Journal of Business Ethics, 109(4), 483-500.

79. Turró, A., Urbano, D., \& Peris-Ortiz, M. (2014). Culture and innovation: The moderating effect of cultural values on corporate entrepreneurship. Technological Forecasting and Social Change, 88, 360369.

80. Ukko, M. S. and J. (2013). A conceptual framework for the measurement of innovation capability and its effects. Baltic Journal of Management, 7(4 pp.), 355-375.

81. Vora, D., \& Polley, J. V. and D. (2012). Applying entrepreneurial orientation to a medium sized firm. International Journal of Entrepreneurial Behavior \& Research, 18 Iss(3 pp.), 352-379.

82. Watson, K., Hogarth-Scott, S., \& Wilson, N. (1998). Small business start-ups: success factors and support implications. International Journal of Entrepreneurial Behaviour \& Research, 4(3), 217-238.

83. Wolff, J. A., Pett, T. L., \& Ring, J. K. (2015). International journal of entrepreneurial behavior \& research small firm gowth as a function of both learning orientation and entrepreneurial orientation: an empirical analysis. International Journal of Entrepreneurial Behavior \& Research, 21(5), 709-730.

84. Yu, X., Nguyen, B., \& Chen, Y. (2016). Internet Research internet of things capability and alliance: Entrepreneurial orientation, market orientation and product and process innovation. Internet Research, 26(2), 402-434.

85. Zafir, M. M., \& Fazilah, M. H. (2011). Entrepreneurial success: An exploratory study among entrepreneurs. International Business and Management, 6(1), 116-125.

86. Zahra, S. A. (2005). Enterpreneurial Risk Taking in Family Firms. Family Business Review, 18(1), 2340.

87. Zhang, H., Zhang, T., Cai, H., Li, Y., Huang, W. W., \& Xu, D. (2014). Proposing and validating a fivedimensional scale for measuring entrepreneurial orientation: An empirical study. Journal of Entrepreneurship in Emerging Economies, 6(2), 102-121.

88. Zulkifli, M., \& Rosli, M. (2013). Entrepreneurial orientation and business success of Malay entrepreneurs: Religiosity as moderator. Ijhssnet, 3(10), 264-275. 